\title{
Bending the Arc of Chinese History: The Cultural Revolution's Paradoxical Legacy
}

\author{
Andrew G. Walder
}

\begin{abstract}
Contrary to its initiators' intentions, the Cultural Revolution laid political foundations for a transition to a market-oriented economy whilst also creating circumstances that helped to ensure the cohesion and survival of China's Soviet-style party-state. The Cultural Revolution left the Chinese Communist Party and civilian state structures weak and in flux, and drastically weakened entrenched bureaucratic interests that might have blocked market reform. The weakening of central government structures created a decentralized planned economy, the regional and local leaders of which were receptive to initial market-oriented opportunities. The economic and technological backwardness fostered by the Cultural Revolution left little support for maintaining the status quo. Mao put Deng Xiaoping in charge of rebuilding the Party and economy briefly in the mid-1970s before purging him a second time, inadvertently making him the standard-bearer for postMao rebuilding and recovery. Mutual animosities with the Soviet Union provoked by Maoist polemics led to a surprising strategic turn to the United States and other Western countries in the early 1970s. The resulting economic and political ties subsequently advanced the agenda of reform and opening. China's first post-Mao decade was therefore one of rebuilding and renewal under a pre-eminent leader who was able to overcome opposition to a new course. The impact of this legacy becomes especially clear when contrasted with the Soviet Union in the 1980s, where political circumstances were starkly different, and where Gorbachev's attempts to implement similar changes in the face of entrenched bureaucratic opposition led to the collapse and dismemberment of the Soviet state.
\end{abstract}

Keywords: Chinese Cultural Revolution; post-Mao reform; Deng Xiaoping; Gorbachev

There are two ways of thinking about historical legacies. The first and most common refers to surviving practices or ways of thought that reflect the continuing influence, whether conscious or unconscious, of an earlier period. The second is less common, and refers to legacies that are hidden or counter-intuitive. In 
this second sense, a prior period can shape subsequent ones by altering a country's historical trajectory, leading to present circumstances that are very different than would otherwise have been the case. Thus, the present can be the product of the past in ways that do not directly reflect earlier practices or ways of thought. This essay is about the latter type of legacy. The argument, in brief, is that the Cultural Revolution made it more likely that the Chinese Communist Party (CCP) would turn away from a Soviet-inspired development model, implement reforms in a deep and sustained fashion, and do so while maintaining CCP cohesion and stability - in fact strengthening and revitalizing its Soviet-inherited political institutions. This is in sharp contrast to the final years of the Soviet Union, where belated initial attempts to implement economic restructuring were blocked by powerful vested interests, leading to moves to open up the Soviet political system in ways that inadvertently generated disintegration and collapse.

The living legacy of the Cultural Revolution, in other words, is a communist party that has survived the transition to an utterly transformed economic system that bears little resemblance to the Soviet model; however, it has done so by holding on tightly to a somewhat modified but fundamentally unreformed version of Soviet-style political dictatorship. This outcome, of course, was not at all what the initiators of the Cultural Revolution intended; in almost every sense, it is the virtual opposite and is impossible to square with any version of Maoist ideology. China today is the very definition of what the Cultural Revolution was intended to forestall. It is a caricature of a Maoist's worst nightmare: the degeneration of the Party into a capitalist oligarchy with unprecedented levels of corruption and inequality. This does not mean simply that the Cultural Revolution failed to achieve its goals; it actually created political circumstances that facilitated the turn to market reform and enhanced the regime's prospect for survival, making China's trajectory so different from that of the Soviet Union. ${ }^{1}$

There is a sense among observers of China that the Cultural Revolution paved the way for subsequent reform. According to Thomas Bernstein, "When it ended, the elite and the population were exhausted, traumatized, and repelled by years of class struggle ... The public longed for stability and a better life ... the country was ready for something new." 2 And, as Arne Westad has observed, "one of its key effects was probably to kill off Marxism as a credible framework for China's development." ${ }^{3}$ This is certainly part of the story. These observations bear on the motivations of leaders, but there remains the puzzle of how China's leaders were able to pull off complex and potentially destabilizing changes without undermining the survival of the Party itself. China's path of

1 This is an argument about the political circumstances that facilitated market reform - it is not about the reforms' relative success compared to other transitional economies. The political disruptions that accompanied regime change in other socialist states, especially the Soviet Union, generated deep recessions that immediately put their post-communist reforms on a different economic trajectory. See Walder, Isaacson and $\mathrm{Lu} 2015$.

2 Bernstein 2013, 43.

3 See Westad 2010, 67, 71-75, for a more detailed analysis of its impact on elite ideological trends. 
reform has frequently been placed alongside that of the Soviet Union under Gorbachev, and the comparisons usually focus on differences in the political and economic strategies of the two nations' leaders: the Soviet approach being overly broad, ambitious and uncoordinated, while the Chinese approach has been more gradual, cautious and focused. ${ }^{4}$ The Cultural Revolution, however, shaped China's trajectory prior to the era of reform in ways that created circumstances very different to those that prevailed in the USSR, and facilitated both the shift to market reform and the Party's survival.

This impact is clearest when we look at China at the beginning of the Deng Xiaoping 邓小平 era alongside the Soviet Union at the start of the Gorbachev era, and note the strikingly different challenges that each leader faced. Four of these differences loom as especially important in setting the two largest communist states on different historical paths.

The first was the Cultural Revolution's devastating impact on the party-state. In the Soviet Union, the Communist Party, the economic bureaucracy, the security services and armed forces had all enjoyed several decades of post-Stalin stability, and in the mid-1980s they represented an array of powerfully entrenched vested interests that stood directly in the way of economic restructuring. In sharp contrast, the Cultural Revolution at some point attacked and disrupted virtually every one of these institutions and their leaders, and their restoration was hampered by controversy and conflict. These institutions had yet to be rebuilt and consolidated at the end of the 1970s, and they lacked the ability of their Soviet counterparts to block the initiatives of a reform-minded leader.

Second, the latter years of the Cultural Revolution inadvertently elevated a senior leader who became the standard bearer for both the revival of party-state institutions and economic restructuring. Deng Xiaoping, at Mao's behest, had a vigorous but abortive role in rebuilding these institutions in 1974 and 1975. This identified him with the revival of Party and state institutions, aligning the interests of Party bureaucrats with those of a senior leader who continued this rebuilding even more vigorously during the 1980s. After Mao's death, Deng accelerated the process of restoring disgraced officials to their former prominence, creating political allegiances that enhanced his authority and his ability to direct the process of change. By contrast, as the youngest member of the Soviet Politburo, Gorbachev's authority was stronger on paper than in reality. He eventually tried to open up the political system to circumvent the vested interests arrayed against reform - a fateful move that led to the spiralling collapse of the Soviet Union.

4 See Bernstein 2013 for a compelling comparative analysis along these lines. Central to Bernstein's analysis is the success of China's economic reforms versus the failure of those of Gorbachev, a difference that contributed to the survival of the CCP and to the collapse of the USSR. My argument is different: I contend that the Cultural Revolution created conditions that made market reform politically feasible in ways that were not the case in the Soviet Union, in particular because market reform coincided with the rebuilding and strengthening of a badly weakened party-state. 
Third, the Cultural Revolution hampered economic development and eroded the country's scientific and technical capacities. China's relative backwardness bred a widespread sense of urgency about economic restructuring that was lacking in the Soviet Union. The economy recovered from the disastrous Great Leap Forward by the mid-1960s, but growth was hampered once again during the Cultural Revolution, during which even more severe damage was inflicted on China's educational and scientific institutions. China remained backward, falling further behind. Although Soviet growth rates had slowed since the 1950s and consumer living standards lagged far behind those of its Western rivals, the Soviet economy was still the world's second largest well into the 1980s, making it a formidable military superpower. Its scientific and technical infrastructure was substantial and world class in some areas. The argument that the Soviet Union was failing to keep pace with the West lacked the sense of urgency of late 1970s China.

Fourth, China's attacks on Soviet "revisionism" during the early 1960s intensified during the Cultural Revolution and generated mutual animosities that threatened to turn into armed conflict by 1969. This prompted Mao's strategic turn towards the United States in 1971 and the gradual revival of ties with Western nations and Japan in the ensuing years. China's strategic realignment with the United States in opposition to a revisionist and "social imperialist" Soviet Union built foundations for a broader opening to Western market economies by the end of the 1970s. The normalization of diplomatic relations with the United States in 1979 completed this process, turning the world's leading market economies into partners eager to assist China's reform and opening. In contrast, hostilities with the Soviet Union further deepened at the end of the 1970s, especially so with the 1979 invasion of Afghanistan and the subsequent boycott of the 1980 Moscow Olympics. Gorbachev could not create a similar opening to the West until he began to withdraw Soviet troops from that country in 1987.

\section{The Destruction of the Party-State Bureaucracy}

The Cultural Revolution devastated China's party-state bureaucracy, and for a period essentially eliminated the Communist Party as a coherent national organization. In the first stage of the campaign in 1966, entire departments of the Central Party apparatus were abolished and combined into small working groups, and the majority of their occupants were set aside for investigation and purge. By the end of 1966, civilian Party organizations throughout the country ceased to operate, as rebel groups composed of students and workers kidnapped officials and occupied Party and government offices. Even worse, lower-ranking Party cadres rebelled against their own superiors in a cascading wave of power seizures that reached far down into the grassroots. ${ }^{5}$ Rebels in counties and cities 
across the country overthrew top officials, which set off a new round of power struggles with rival rebel groups that continued in most regions well into 1968. The impact on the structure of the party-state can hardly be understated - the apparatus of civilian rule was effectively destroyed. ${ }^{6}$

The 1968 imposition of military control appeared to mark the restoration of order, and indeed, the large-scale street battles came to an end as the military dismantled independent rebel organizations and punished their most strident leaders. In the place of the former structures of government and Party committees a new form of government was established - a "revolutionary committee" made up of a minority of surviving civilian officials, token rebel leaders, and military officers loyal to the local PLA commander who, in most cases, occupied the top position. In most parts of the country, revolutionary committees were a thinly disguised form of military dictatorship. ${ }^{7}$

The new revolutionary committees initially oversaw the further dismantling and downsizing of what remained of the party-state bureaucracy. The vast majority of civilian officials and support staff in government organs, Party offices, newspapers and other public institutions were shipped off to rural camps, described as "May 7 cadre schools," for indefinite terms of reform through labour. Entire departments were consolidated into working groups that were operated by a skeleton staff left behind in the cities. The numbers of officials "sent down" in this fashion are startling - up to 70 per cent of all officials in some provinces. For a period, it appeared that this massive downsizing of the government apparatus was intended to be permanent. The evacuation of civilian officials and staff only enhanced the dominance of military officers in government administration. $^{8}$

These rural camps were closed after the Lin Biao 林彪 affair in late 1971, and efforts to rebuild the national bureaucracy began. Mao had the ranks of the military commanders purged of those deemed loyal to Lin Biao, and the authority of the remaining military commanders over civilian administration went into decline. Mao gave Zhou Enlai 周恩来 the authority to begin the huge task of reviving China's administrative apparatus and rebuilding the Communist Party. The rebuilding of Party committees and branches got underway in 1972, and officials purged earlier in the Cultural Revolution began to return to their posts. ${ }^{9}$

Yet, for the remaining four years of Mao's life, this rebuilding process remained a source of division and conflict. Zhou soon came under attack for moving too fast and too far to restore the status quo ante. He was sidelined during the 1974 "Criticize Lin Biao and Confucius" campaign as Maoist radicals pushed back against the "tide of restoration." The campaign revived factional conflict and street battles on a scale not seen since 1968 in what people at the

6 These developments are documented in MacFarquhar and Schoenhals 2006, 132-238; Walder 2015, 233-253.

7 See Bu 2008, 235-37; Dong and Walder 2012b; MacFarquhar and Schoenhals 2006, 239-246.

8 Walder 2015, 270-71.

9 MacFarquhar and Schoenhals 2006, 337-347; Teiwes and Sun 2007, 25-85. 
time described as a "Second Cultural Revolution," through which former rebels aspired to a "second power seizure." The civil disorders, often focused on large state factories and the railway system, halted the fragile revival of the economy. ${ }^{10}$

Mao then decided to elevate Deng Xiaoping to Zhou's former position in order to restore "stability and unity." Deng launched a rectification campaign to remove disruptive radicals from positions of authority, purge the PLA ranks of officers who refused to accept Party discipline, vet the ranks for disruptive Party members who had joined in recent years, and continue to rebuild the Party as a disciplined organization. However, in early 1976, Deng, too, was purged for going too far, and resurgent rebels resumed their attacks on the restoration of former officials, undoing much of Deng's recent labours. These attacks were halted only after Mao's death and the October arrests of the "Gang of Four." 11

This brief review of the impact of the Cultural Revolution on the CCP and the civilian bureaucracy illustrates the central point. The entire structure of civilian rule was effectively paralysed from 1966 to 1968; what remained was further dismantled under military rule, and efforts to rebuild it made the national administration a battleground of warring factions. One of the most consequential accomplishments of the Cultural Revolution was that it severely damaged the national bureaucracy, leaving it weak and divided. At the end of the 1970s, it was anything but an entrenched and powerful force capable of defending its privileges and vested interests. Officials at this point in time were grateful to be returned to responsible positions, given real authority over their designated areas of operation, and freed of the constant threat of political accusations for alleged errors. The post-Mao characterization of the Cultural Revolution as a "decade of chaos" applies with particular force to the structures of national government.

The destruction of the national bureaucracy also had an inevitable structural consequence - a drift towards decentralization and local self-reliance. Budgeting and planning had long since devolved to provinces and localities. In the absence of strong central direction, local authorities became increasingly responsible for devising development strategies. A decentralized fiscal structure meant that local officials, especially in townships and villages, had a strong pecuniary interest in locally generated revenues that derived from market-oriented entrepreneurship, whether based on small family enterprises or somewhat larger government-founded firms. This turned local Party and government officials - as opposed to central bureaucrats - into active proponents of market-oriented reform. The rapid spread of household farming, small family businesses, and, somewhat later, the explosive growth of township and village enterprises, was a product of this prior decentralization, which turned the local state into a powerful constituency for reform. ${ }^{12}$

10 Dong and Walder 2012a; Forster 1990, 139-176; Teiwes and Sun 2007, 146-185.

11 MacFarquhar and Schoenhals 2006, 378-395; Teiwes and Sun 2007, 245-282, 305-381; Vogel 2011, 91-153.

12 On the decentralization of state structures and economic activity in Mao-era China, see Donnithorne 1972; Oksenberg and Tong 1991; Shue 1988; White 1998. Westad 2010, 66-71 provides a cogent 
When Gorbachev set out to restructure the Soviet economy along more modern and market-oriented lines in the late 1980s, he faced a fundamentally different situation. The Soviet Communist Party, its national apparatus of ministries and bureaus, its massive security apparatus and huge military establishment had not experienced extensive purges for almost 40 years. These centralized structures had grown and enhanced their authority, had accumulated bureaucratic privileges, and were well prepared to defend both against reforms that threatened the status quo. Gorbachev quickly found that his attempts to initiate economic reforms met with delay and obstruction. ${ }^{13}$ One response in 1988 - quite radical in nature - was to remove Communist Party organs from oversight of state enterprises and free the enterprises to engage in market-oriented activities. This attempt to kickstart economic reform initiated an irreversible deterioration of the Soviet economy. ${ }^{14}$ Gorbachev began to devise ways of going around his more conservative colleagues by appointing his own special advisors and encouraging independent think tanks. ${ }^{15} \mathrm{He}$ eventually concluded that the only way to overcome bureaucratic resistance to reconstruction, or "perestroika," was to reduce the power and influence of the bureaucracy and neutralize the security services and armed forces. This was the origin of "glasnost," a greater transparency and openness about the flaws and inequities of the Soviet system, past and present, which was a prelude to an attempt to restructure the political system through competitive elections to new national assemblies. ${ }^{16}$ By the spring of 1989, Party secretaries of regions and cities were made to stand for election to legislative assemblies, and many of them lost. The momentum of democratization within Soviet structures, however, split the Communist Party and turned into nationalist mobilization that tore the Soviet Union apart. ${ }^{17}$

One can find fault with Gorbachev's political strategy - clearly, he lost control of the process of liberalization - but it is beyond dispute that he faced an array of opposing forces infinitely more powerful than those facing Deng Xiaoping in China. Had the Cultural Revolution not occurred, and if the Party apparatus and national bureaucracy had grown undisturbed, China's bureaucrats may not have become the powerfully entrenched force, as represented by those in the Soviet Union, but they would have been much stronger than they were in the wake of the Cultural Revolution. Mao's attacks on China's bureaucrats had cleared the way for Deng Xiaoping, who would move in a direction utterly different to the one Mao had in mind.

footnote continued

overview of a range of such informal economic practices in the 1970s. On the consequences for local development, especially in rural regions, see Oi 1992; Walder 1995; 1998; Yang 1996.

13 For examples, see Bernstein 2013, 51-54.

14 Ellman and Kontorovich 1998; Gregory 2004.

15 Brown 1996, 130-154; 2007, 69-101.

16 Brown 1996, 155-211; 2007, 103-153.

17 Beissinger 2002; Brown 1996, 252-305; Gill 1994, 78-173. Bernstein 2013, 57-61 provides a concise overview of these final years. 


\section{Elevating Deng Xiaoping's Post-Mao Authority}

I have just argued that the array of forces against reform and restructuring faced by Deng Xiaoping were far less formidable than those facing Gorbachev, and that the key reason was the Cultural Revolution. However, we should also consider the other side of the coin - the relative authority of Deng versus Gorbachev. While the Soviet bureaucracy was much more powerfully entrenched than China's, Deng Xiaoping also had much more personal authority than Gorbachev. This, also, was owing, to a considerable extent, to the Cultural Revolution and in particular to the twists and turns of its later stages.

We have already seen that in late 1974 Mao entrusted Deng Xiaoping to continue the task begun by Zhou Enlai, who was by then under attack and seriously ill, to rebuild the Party and government and finally eliminate the role of the PLA in civilian administration. Deng did this with vigour and acted with much greater boldness than Zhou to restore order following the "Second Cultural Revolution" of 1974. He moved decisively to end the disruptions to the railway system and major state enterprises by launching rectification campaigns to restore the authority of Party secretaries and purge rebel rivals and their followers, imprisoning several prominent local rebels in the process. He continued the rehabilitation of disgraced officials and began to lay plans to restore China's educational system especially the ravaged universities - and to revive research institutes and scientific and technical research. ${ }^{18}$ In so doing, he became the standard bearer for the restoration of former officials to their posts and the re-creation of the structures of power that predated the Cultural Revolution. This predictably drew the ire of Maoist radicals on the Politburo and their adherents throughout the country, who convinced Mao that Deng had gone too far. Deng was sidelined in January 1976, disappeared from public view, and was the barely concealed target of a new campaign to criticize an "unrepentant capitalist roader." After the Tiananmen demonstrations of April 1976, he was officially removed from his posts and made the target of a campaign to "criticize Deng." 19 The animus directed at Deng made him the leading villain for Mao's radical loyalists, but it also ensured that Deng would become the acknowledged hero of all those who sought to rebuild the structures of the party-state, purge it of disruptive rebels, and rebuild the Party, economy, and scientific and technical infrastructure. The way in which Deng rose to supplant Hua Guofeng 华国锋 as the Party's pre-eminent leader at the end of 1978 is testament to the widespread political support that he earned for his efforts during Mao's last years. ${ }^{20}$

By contrast, when Gorbachev was appointed general secretary of the Communist Party of the Soviet Union at the age of 54 in 1985, he was the youngest member of both the Politburo and Central Committee Secretariat. He was the youngest member of the Politburo by five years, and 13 years younger than the

18 Dong and Walder 2014; Teiwes and Sun 2007, 306-363; Vogel 2011, 91-140.

19 Vogel 2011, 141-172.

20 Baum 1994, 48-56; MacFarquhar and Schoenhals 2006, 451-53; Vogel 2011, 217-248. 
average age of Politburo members at that time. He had secured positions on both the Politburo and Secretariat only five years before, in $1980 .{ }^{21} \mathrm{He}$ was surrounded by more senior figures, the most conservative of whom had served at the apex of the party-state for more than thirty years. Gorbachev's authority at this point was in many ways comparable to Hua Guofeng's in 1976. ${ }^{22}$ They both held the top Party and government posts but were relative newcomers to the top echelons and did not have extensive networks of support in the upper reaches of the Party.

The contrast in the authority held by Gorbachev and that enjoyed by Deng is sharpened by the differences in the political opportunities that were available to them. Gorbachev's progressive ideas threatened the vested interests of an entrenched bureaucracy that had grown undisturbed for decades and which now oversaw an enormous military-industrial complex. Deng Xiaoping was in a fundamentally different position. In 1976, he was 71 years old and a veteran of the top reaches of the Party. He had assumed top national posts in Beijing in 1952 before joining the Politburo and becoming the Communist Party's general secretary in 1956. After Mao's death, he was the recognized leader of those who sought to rebuild the bureaucratic institutions destroyed in previous years and resurrect the Communist Party's unity and strength. After Deng Xiaoping returned to political pre-eminence at the end of 1978, he continued the restoration process that was hampered and delayed for so long during the 1970 s. ${ }^{23}$ Disgraced and sidelined officials were more rapidly rehabilitated, disruptive rebels were systematically purged, and the Party underwent a series of rectification campaigns to identify and punish those who had collaborated with the "Gang of Four." The rectification and rebuilding continued well into the 1980s.

In short, Deng represented the resurrection of the same forces whose vested interests stood in the way of Gorbachev. Deng was leading the way to their recovery towards a more secure and prosperous future, and as it turned out, an integral part of this package of national revival was the restructuring of China's command economy. The Cultural Revolution eased the politics of economic reform by bundling that programme together with the revitalization of the party-state. This opportunity was not available to Gorbachev.

\section{Deepening China's Relative Backwardness}

The case for a fundamental restructuring of a Soviet-style economy is strengthened by incontrovertible evidence that the system is failing. The Cultural Revolution enhanced China's relative backwardness in ways that made decisive action seem urgent. The Soviet economy had long laboured under well-known inefficiencies, leading to a gradual stagnation of growth rates, inefficient

22 Vogel 2011, 185-87 describes Hua's position in similar terms.

23 Lee 1983. 
allocation of capital, lagging technological innovation, and poor delivery of consumer goods and services. These flaws were widely discussed in the Soviet bloc as early as the 1950s. ${ }^{24}$ Yet, the Soviet Union still had the world's second largest economy into the late 1980s. It was highly urbanized in ways typical of a modern industrial society, and its military-industrial complex was a major challenge to its Cold War rivals. China's economy had experienced a self-inflicted crisis; the Soviet Union's problems were far less dramatic.

When reliable data on China's economy became available early in the post-Mao era, its level of backwardness and poverty was startling. Adjusted for price and exchange rate distortions, China's per capita GDP in 1976 was US\$852 - much higher than Bangladesh (US\$540), Burma (US\$687) and Nepal (US\$654), slightly below India (US\$889), and well below Indonesia (US $\$ 1,598$ ), Pakistan (US\$1,006) and Malaysia (US\$2,910). South Korea's per capita GDP was four times higher than China's (US\$3,476), and Taiwan's per capita GDP was more than five times higher (US\$4,600). In total size, China's economy (US\$793 billion) was only half the size of Japan's economy (US\$1.3 trillion). ${ }^{25}$

The 1976 figures did not simply reflect the undeniable fact that the People's Republic of China in 1949 had started at a severe disadvantage: China had actually fallen further behind after the 1950s, and if trends had continued, would have permanently remained so. Although Japan's economy was twice the size of China's in 1976, China's economy in 1950 was 50 per cent larger than Japan's, and it would remain considerably larger until the aftermath of the Great Leap Forward. ${ }^{26}$ In 1950, South Korea's GDP per capita was 1.7 times China's figure; by 1976, the ratio had grown to 4.4. In 1950, Japan's GDP per capita was 4.4 times that of China; by 1976, the ratio had grown to 13.7. By these same measures, China had clearly outperformed only the worst cases of underdevelopment in the region such as Bangladesh, Burma and Nepal. China's one accomplishment by 1976 was to have closed the gap with India. ${ }^{27}$ Figure 1, which displays trends in GDP per capita, provides a visual sense of these trends. China fell further behind not only nearby East Asian economies but also the "revisionist" economies of the Soviet Union and Eastern Europe. Figure 1 makes clear that the gap expanded rapidly after 1966. While much of East Asia was beginning to take off, China was mired in self-inflicted stagnation.

24 Kornai 1959; Liberman 1971; Šik 1967. These discussions influenced Chinese economists at the time as well: Fung 1982; Lin 1981.

25 Maddison 2006, 298, 304-05. These figures are adjusted for purchasing power parity, which corrects for distortions owing to exchange rates and differences in domestic prices. The conventional measures at the time, which did not make these adjustments, make China's economy look much worse in relative terms, and they are likely to be the figures that China's leaders worked with in the early post-Mao era. Compare with the standard Gross National Income measures of the World Bank: data.worldbank. org/indicator.

26 Maddison 2006, 298.

27 Ibid., 304-05. 
Figure 1: Growth Trends, China and Selected Countries, 1950-1976

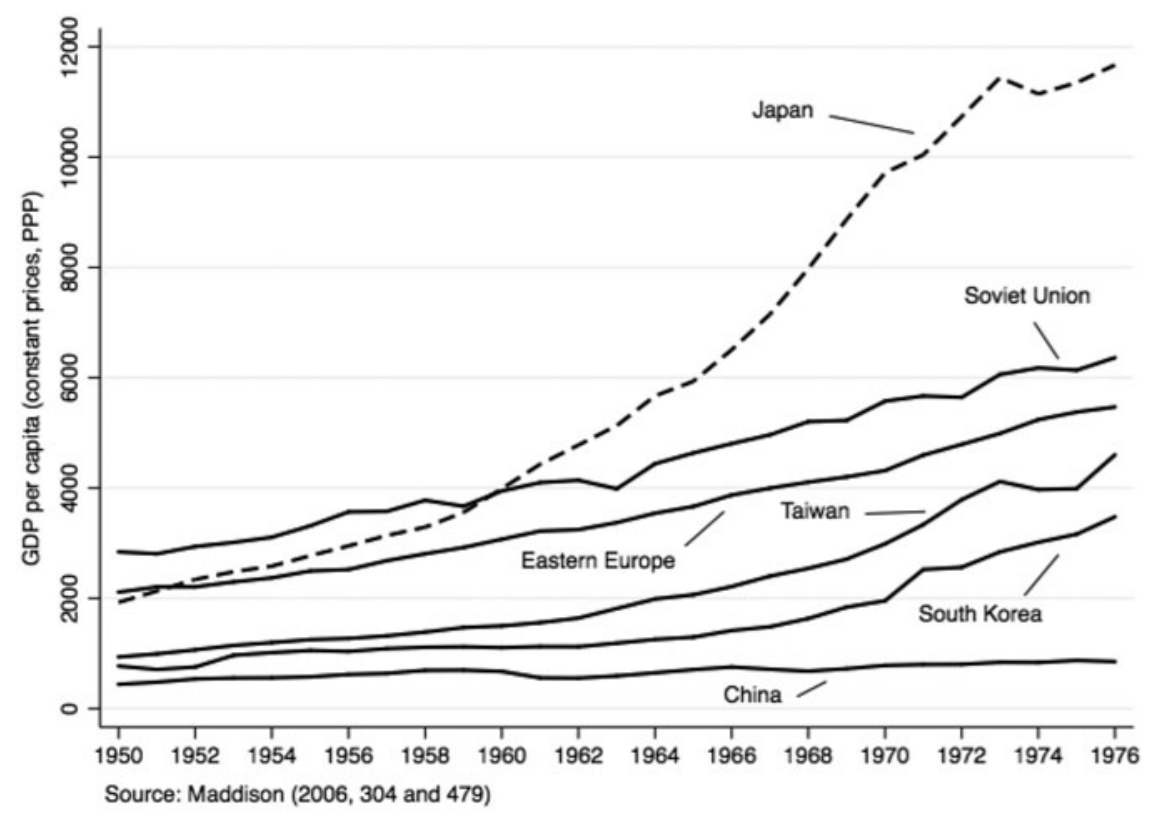

China's growth trajectory made it more directly comparable to Asian nations still mired in poverty. Figure 2 charts China's growth relative to India, Bangladesh, and Pakistan, and it shows more clearly than Figure 1 the fluctuations in China's development. China began with a lower level of development than any of these countries in 1950, and caught up with or surpassed them rapidly during the 1950s. The Great Leap Forward threw China sharply backward when compared to India and Pakistan - in fact, back to the same level as Bangladesh. There followed a strong recovery in the early 1960s, leading China once again to almost catch Pakistan and India by 1966. However, China was thrown backward once again by the Cultural Revolution. Inconsistent growth resumed after 1968, and by 1976, China had once again almost caught up with India, thanks primarily to India's stagnating economy. This record was nothing for China's political elite to celebrate, especially in light of the comparisons in Figure 1.

The Cultural Revolution was less damaging to China's economy than the Great Leap Forward, which saw GDP per capita shrink by 17 per cent in 1961 alone, but it did greatly slow China's development. China's GDP per capita shrank by 5.5 per cent in 1967 and another 4.7 per cent in 1968, before recovering in 1969 and 1970. After that point, average annual growth by this measure was only 1.5 per cent - there was virtually no growth in 1972 and the economy shrank in 1974 and $1976 .{ }^{28}$ The sluggish growth was not solely owing to political 
Figure 2: Growth Trends, China and Poor Asian Nations, 1950-1976

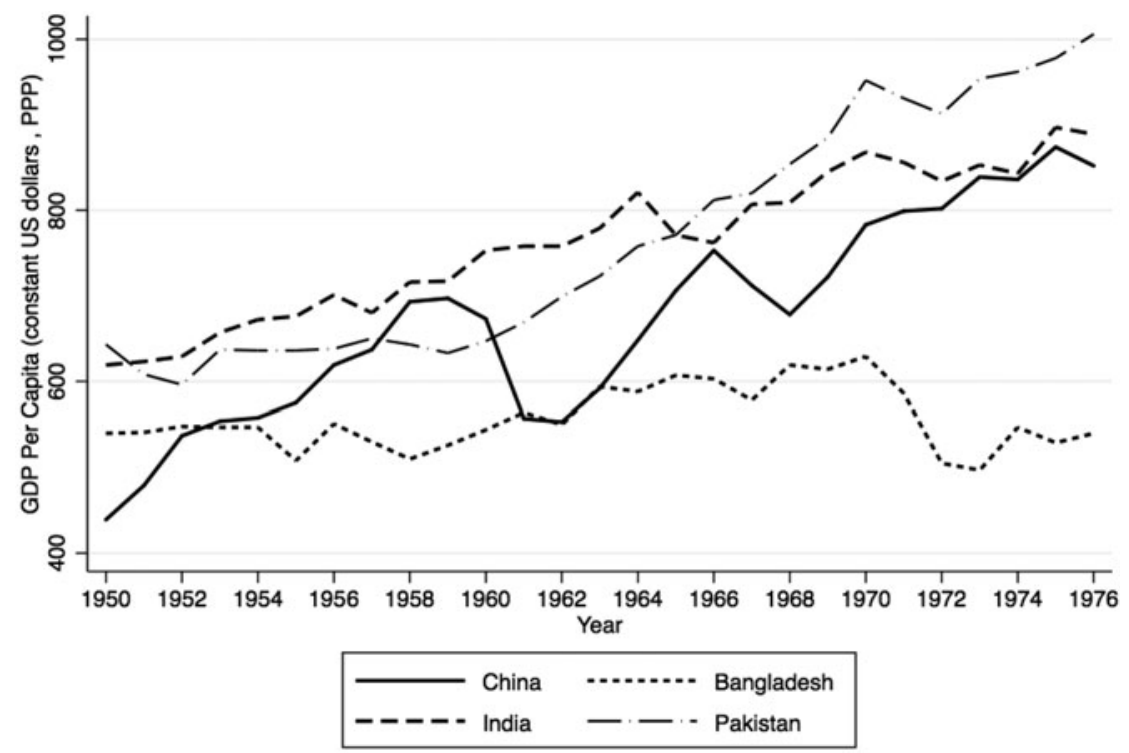

Source: Maddison (2006, 304-305)

upheavals; it was also due to a system of agriculture that was barely able to increase output enough to keep pace with a rapidly growing population, and to an inefficient heavy industrial sector that absorbed an unusually high percentage of national investment at the expense of consumer goods, services and housing. The heavy industrial sector alone absorbed 52 per cent of national investment in 1953, and it took more than 80 per cent almost every year after the mid-1960s. ${ }^{29}$ Industry deployed its abundant resources very inefficiently. There were negative returns to investment in industry in 1967 and 1968, and, after a brief recovery, returns to investment declined steadily after 1971. By the end of the Mao era, industry was barely producing positive returns. ${ }^{30}$

These figures indicate a development model that was in serious trouble, and by the end of the Cultural Revolution, the symptoms of backwardness and hardship were impossible to ignore. Effectively frozen during the Cultural Revolution, average industrial wages fell close to 15 per cent from 1964 to 1976. Staple foods and a range of consumer goods were allocated through ration coupons, and consumer goods were frequently of poor quality and in notoriously short supply. Housing supply was inadequate and older buildings were deteriorating badly. Overinvestment in heavy industry came at the expense of urban housing, which fluctuated between 2.5 and 6.5 per cent of capital investment after $1966-$ compared to the 1953 figure of 12.5 per cent. The result was average urban 
housing space of 3.6 square metres per person in 1976 - significantly worse than in 1956, when the figure was 4.3 metres in cities that were already overcrowded. ${ }^{31}$ Rural living standards were much worse than those in cities. At the end of the 1970s, one-fifth of the rural population existed on a diet that was below the subsistence level of daily calorie consumption defined by the Chinese government - a figure that was lower than that stated by international agencies. Average daily calorie consumption in rural China was slightly higher than in India but lower than in Indonesia and Pakistan. Early post-Mao surveys of rural living standards generated official estimates that 30 per cent of the rural population, some 237 million people, lived on incomes that were below the poverty level. ${ }^{32}$

The symptoms of deepening backwardness were impossible to ignore. China was no longer catching up and was in danger of falling even further behind. It was easy to make the case for drastic measures, and there was precedent for this in the history of the regime. In the aftermath of the Great Leap Forward, Liu Shaoqi 刘少奇 had taken the lead in defining the economy as a disaster area that required emergency measures, including a reversion to household agriculture on a scale that appalled Mao Zedong. ${ }^{33}$ With Mao dead and his followers in prison, Deng Xiaoping was free to revert to the post-Great Leap playbook and make up for years of lost time. The Cultural Revolution made the case for the fundamental restructuring of the economic system much more convincing. There was no plausible case for staying the course; it would be impossible to argue that China risked much by moving in a new direction.

In the Soviet Union, by contrast, the problem was slowing growth and a system that failed to deliver consumer prosperity and industrial innovation. The lack of productivity and innovation in the Soviet economy prevented it from catching up with Western market economies. In 1950, Soviet GDP per capita was only 30 per cent of that of the United States; in 1980, after 30 years, this had only grown to 35 per cent. The comparison with Japan was even less favourable. Soviet GDP per capita was 50 per cent larger than Japan's in 1950, but it was only half of Japan's in $1980 .{ }^{34}$ The shortcomings of the economic model were well known and were widely discussed as early as in the 1950s. Changes to the system remained ideologically controversial, and the proposed reforms did not make much headway except in Yugoslavia and, to a more limited extent, Hungary. From the 1950s through to the mid-1980s in the Soviet Union, efforts to implement relatively modest reforms were consistently sidetracked. The system had, after all, turned the Soviet Union into a major industrial economy and a military superpower, and its economy remained the world's second largest until it was overtaken by Japan in 1988. ${ }^{35}$ Moreover, the USSR was locked in a Cold War confrontation that 
intensified in the late 1970 s. The Soviet Union, unlike China, potentially had a great deal to lose.

\section{Strategic Alignment with the West}

The final way in which the Cultural Revolution bent the arc of Chinese history is perhaps the most paradoxical of all: the strategic turn towards the United States as a counterweight to the Soviet Union. What made sense as geopolitical strategy made virtually no sense in ideological terms.

Maoist polemics against the Soviet Union on the eve of the Cultural Revolution led to the mutually antagonistic Sino-Soviet split, over both domestic and foreign policy issues. Domestically, Maoist ideologues denounced the Soviet Union for declaring that class struggle against domestic class enemies was dead, and that the primary task of socialism was to build the economy and improve people's livelihoods. Maoists charged that this gave educated bourgeois experts authority over the working class, that the Soviet wage scales gave excessive salaries and privilege to the highly placed, and that material incentives like piece rates and bonuses were exploitative and did not give play to moral and political incentives that were the hallmark of revolutionary socialism. The relaxation of domestic class struggle and the reliance on experts and material incentives, in this view, showed that the Soviet Union was revisionist and well on the road to restoring capitalism. The polemics against the USSR in 1963 and 1964 laid out what became the ideological justification for the Cultural Revolution, and in particular for the charge that Liu Shaoqi, who allegedly favoured Soviet-like policies, was "China's Khrushchev."

The denunciation of the Soviet Union also had a foreign policy dimension. Mao was adamantly opposed to a relaxation of the confrontation with imperialism, and especially with the United States, and reacted very negatively to Khrushchev's efforts to reduce superpower tensions. The Maoist view was that global confrontation with imperialism was inevitable and necessary, and that support for armed national liberation struggles throughout the world was the only truly revolutionary position. To relax tensions with the West was to abandon revolution, yet another sign that the Soviet Union was a revisionist nation that had betrayed the ideals of world revolution. The final break with the Soviet Union occurred shortly after the USSR signed a nuclear test ban treaty with the United States in 1964. From that time forward, the polemics against the Soviet Union intensified and Mao prepared his Cultural Revolution to ensure that China would never take the Soviet road. ${ }^{36}$

By 1969, the mutual animosities with the Soviet Union had reached the point of armed border clashes. Worried about the military threat of a hostile superpower on China's northern border, Mao began to rethink his geopolitical 
strategy. Secret negotiations with the United States in 1971 led eventually to a visit by Nixon in 1973 - a startling rapprochement with the United States. ${ }^{37}$ This was a triumph of geopolitical pragmatism over ideology. ${ }^{38}$ The denunciation of the Soviet Union had originated in a protest against accommodation with the West, but now China far surpassed the USSR in accommodation - despite the United States' ongoing war in Vietnam. The break with the Soviet Union for relying on scientists and providing bonuses for workers now stood in stark contradiction with China's reconciliation with the world's leading capitalist and imperialist power. China declared its militant opposition to Soviet "hegemonism" and would soon castigate the USSR as "social imperialist," an incoherent inversion of the polemics of a decade before. This turn towards the West was an entirely unanticipated consequence of the Cultural Revolution's harsh polemics against Soviet "revisionism." 39

Ties with the West remained controversial in the last years of the Mao era, and Zhou Enlai was attacked and sidelined in part for his role in the negotiations with the United States. ${ }^{40}$ However, an opening was created that was expanded much further into formal diplomatic and economic ties with leading West European nations and Japan, and eventually with the United States in 1979. ${ }^{41}$ The heightened confrontation with the Soviet Union after the invasion of Afghanistan that year intensified the United States' interest in strengthening ties with China and promoting its economic modernization. This occurred at precisely the time when Deng Xiaoping returned to power and created an opportunity for expanding trade, technology transfer, foreign aid and bank finance, and educational exchanges with a range of Western powers and Japan that became a central prop for the reform and opening initiated under Deng Xiaoping. Denunciation of Soviet revisionism, the hallmark of the Cultural Revolution, was to have consequences that were entirely unforeseen by its instigators.

\section{Conclusion}

There is a final legacy of the Cultural Revolution that is an enduring consequence of the four paths of influence outlined above. This is the identification of state strengthening with the national revival that accompanied Deng Xiaoping's agenda of the 1980s. Analysts of market reform, especially during its early years, frequently viewed the expansion of market allocation as necessarily

37 MacFarquhar and Schoenhals 2006, 308-323.

38 And, according to Westad, also a deeply flawed understanding of world trends. Mao's turn towards a virtual alliance with the United States "originated in one of the great geopolitical misunderstandings of the twentieth century: that the Soviet Union was the ascending superpower and the United States was a power in decline. For Mao Zedong it had become almost an article of faith by the late 1960s that at some point during the coming decade Soviet power would dominate the world, and at that moment, or soon after, the Soviet Union would attack China" (Westad 2010, 76).

39 According to Westad 2010, 79, "Mao's opening to the West was almost an act of panic as confrontation with the Soviet Union seemed to draw nearer."

40 Teiwes and Sun 2007, 85-93.

41 Vogel 2011, 294-348. 
implying a relative decline in state power. ${ }^{42}$ This is persuasive when the issue is viewed narrowly from the perspective of political economy - but it ignores historical differences in the trajectories of these states.

China's market reforms have proceeded alongside the rebuilding and strengthening of a party-state that was badly damaged during the Cultural Revolution. This has created among the post-Mao Chinese elite an enduring attachment to Soviet-era institutions of dictatorship as an indispensable foundation for national greatness. Chinese elites' identification of Soviet institutions of governance with stability and economic success was reinforced by the traumatic (for them) domestic and international events of 1989 to 1991. To the present day, when reflecting on the end of the Soviet Union, China's leaders view Gorbachev's attempts to democratize as the primary cause of national collapse and dismemberment. The relative openness of China's leaders to ideas about political reform in the 1980s has given way to a resurrected hostility to any type of political reform, indeed to any open discussion of such ideas. As a result, there has been little change in the structures of power copied from the Soviet Union in the 1950s.

One clear implication of the analysis presented in this essay is that this view misinterprets the reasons for the Soviet collapse and overestimates the contribution of consolidated dictatorship to China's own national revival. Gorbachev's experience showed that entrenched bureaucratic opposition to reform made the implementation of economic restructuring much more difficult than was the case in China. From a position of relative weakness, he felt compelled to push for rapid political opening and democratization. The strategy failed and led to the collapse of the Soviet state. Had Gorbachev not faced such entrenched bureaucratic opposition, he would not have felt compelled to push the agenda of democratization so aggressively, and it might have been possible to implement market reforms with a more gradual and careful opening of the political system. This opportunity was not available to Gorbachev but has been available to China's leaders for quite some time. Yet, they remain unable to contemplate any significant redesign of their imported Soviet-era political institutions. The story of Soviet collapse could therefore be told as a cautionary tale about the consequences of an entrenched elite that has the power to block reform until it is too late, rather than a story about the inherent dangers of any approach to expanding openness and significant political reform.

China's leaders now preside over a deeply entrenched bureaucracy with enormous vested interests in the private and public wealth generated by economic growth. China's post-Mao experience has convinced them that consolidating a Soviet-style single-party dictatorship is the formula for permanent success. As the Party faces continuing challenges in the struggle to fight corruption and rein in abuses of power - the primary threats to the regime's stability and its popular legitimacy - the CCP would be well advised to think about the last

42 Examples of this kind of reasoning can be found in Walder 1994, which implicitly holds state strength across socialist states as constant, an assumption undermined by the comparative argument in this essay. 
years of the Soviet Union, and the alleged virtues of China's Soviet-style political institutions, in a different light. The Cultural Revolution indeed bent the arc of Chinese history - but with a pronounced twist.

\title{
Acknowledgement
}

Participants in The China Quarterly conference on the "Cultural Revolution's living legacies," and particularly Patricia Thornton and Chris Berry, provided comments that helped the author shape this final draft.

\section{Biographical note}

Andrew G. Walder is the Denise O'Leary and Kent Thiry Professor in the School of Humanities and Sciences at Stanford University, where he is a faculty member in the department of sociology and a senior fellow in the Freeman-Spogli Institute of International Studies. He is the author of Fractured Rebellion: The Beijing Red Guard Movement (Harvard, 2009) and China under Mao: A Revolution Derailed (Harvard, 2015).

\begin{abstract}
摘要: 跟文革发起者的意图相反, 这场运动为市场导向型经济奠定了政治基 础，同时也创造了一个使得苏维埃式党国体制得以在中国保持凝聚并存续 下去的环境。文革削弱了共产党及其政体的结构, 使之变动不居, 并显著 削弱了根深蒂固的官僚利益, 减轻了市场化改革可能受到的阻碍。中央政 府结构的弱化创造了一个去中心化的计划经济体，区域和地方领导人乐于 迎接初期的市场化机遇。经济与科技因文革而极度落后，已经无人愿意维 持现状。1970 年代中期, 毛泽东在第二次打倒邓小平之前, 曾短暂命其负 责政党和经济的重建工作，无意中使他成为后毛泽东时代重建和恢复工作 的领头人。1970 年代初期, 因政治论争所引发的对苏联的共同敌意带来了 一个意外转折，使得中国在战略上倒向美国和其他西方国家，由此而催生 的经济和政治纽带随后推进了中国的改革开放进程。因此，后毛泽东时代 的第一个十年, 是在一名卓越的领导人带领之下克服阻力、走上新轨的重 建与复兴的十年。与上世纪 80 年代的苏联相比, 这一遗产的影响尤为显 著。 80 年代苏联的政治环境截然不同, 戈尔巴乔夫在根深蒂固的官僚利益 面前, 试图实施类似的改革, 却最终导致苏联崩溃解体。
\end{abstract}

关键词: 文化大革命; 后毛时代改革; 邓小平; 戈尔巴乔夫

\section{References}

Baum, Richard. 1994. Burying Mao: Chinese Politics in the Age of Deng Xiaoping. Princeton: Princeton University Press.

Beissinger, Mark R. 2002. Nationalist Mobilization and the Collapse of the Soviet State. New York: Cambridge University Press. 
Bernstein, Thomas P. 2013. "Resilience and collapse in China and the Soviet Union." In Martin K. Dimitrov (ed.), Why Communism Did Not Collapse: Understanding Authoritarian Regime Resilience in Asia and Europe. New York: Cambridge University Press, 40-63.

Brown, Archie. 1996. The Gorbachev Factor. Oxford: Oxford University Press.

Brown, Archie. 2007. Seven Years that Changed the World: Perestroika in Perspective. Oxford: Oxford University Press.

Bu, Weihua. 2008. "Zalan jiu shijie”: wenhua da geming de dongluan yu haojie, 1966-1968 ("Smashing the Old World”: The Catastrophic Turmoil of the Cultural Revolution, 1966-1968). Hong Kong: Zhongwen daxue chubanshe.

Dong, Guoqiang, and Andrew G. Walder. 2012a. "Nanjing's 'Second Cultural Revolution' of 1974." The China Quarterly 212, 893-918.

Dong, Guoqiang, and Andrew G. Walder. 2012b. "From truce to dictatorship: creating a revolutionary committee in Nanjing." The China Journal 68, 1-31.

Dong, Guoqiang, and Andrew G. Walder. 2014. "Foreshocks: local origins of Nanjing's Qingming demonstrations of 1976." The China Quarterly 220, 1092-1110.

Donnithorne, Audrey. 1972. "China's cellular economy: some economic trends since the Cultural Revolution." The China Quarterly 52, 605-619.

Ellman, Michael, and Vladimir Kontorovich (eds.). 1998. The Destruction of the Soviet Economic System: An Insider's History. Armonk, NY: M.E. Sharpe.

Forster, Keith. 1990. Rebellion and Factionalism in a Chinese Province: Zhejiang, 1966-1976. Armonk, NY: M.E. Sharpe.

Fung, K.K. (ed.). 1982. Social Needs Versus Economic Efficiency in China: Sun Yefang's Critique of Socialist Economics. Armonk, NY: M.E. Sharpe.

Gill, Graeme. 1994. The Collapse of a Single-party System: The Disintegration of the Communist Party of the Soviet Union. Cambridge: Cambridge University Press.

Gregory, Paul R. 2004. The Political Economy of Stalinism. Cambridge: Cambridge University Press.

Kornai, János. 1959. Overcentralization in Economic Administration (John Knapp (trans.)). Oxford: Oxford University Press.

Kuan, Chen, Hongchang Wang, Yuxin Zheng, Gary H. Jefferson and Thomas G. Rawski. 1988. "Productivity change in Chinese industry: 1953-1985." Journal of Comparative Economics 12, $570-591$.

Lee, Hong Yung. 1983. "China's 12th Central Committee: rehabilitated cadres and technocrats." Asian Survey 23(6), 673-691.

Liberman, E.G. 1971. Economic Methods and the Effectiveness of Production. White Plains, NY: International Arts and Sciences Press.

Lin, Cyril Chihren. 1981. "The reinstatement of economics in China today." The China Quarterly 85, $1-48$.

Lüthi, Lorenz M. 2008. The Sino-Soviet Split: Cold War in the Communist World. Princeton, NJ: Princeton University Press.

MacFarquhar, Roderick. 1997. The Origins of the Cultural Revolution 3: The Coming of the Cataclysm, 1961-1966. New York: Columbia University Press.

MacFarquhar, Roderick, and Michael Schoenhals. 2006. Mao's Last Revolution. Cambridge, MA: Harvard University Press.

Maddison, Angus. 2006. The World Economy, Volume 1: A Millennial Perspective; Volume 2: Historical Statistics. Paris: OECD.

Oi, Jean C. 1992. "Fiscal reform and the economic foundations of local state corporatism in China." World Politics 45(1), 99-126.

Oksenberg, Michel, and James Tong. 1991. "The evolution of central-provincial fiscal relations in China, 1971-1984: the formal system." The China Quarterly 125, 1-32.

Shue, Vivienne. 1988. The Reach of the State: Sketches of the Chinese Body Politic. Stanford, CA: Stanford University Press. 
Šik, Ota. 1967. Plan and Market under Socialism. White Plains, NY: International Arts and Sciences Press.

State Statistical Bureau. 1983. Zhongguo tongji nianjian 1983 (China Statistical Yearbook 1983). Hong Kong: Xianggang jingji daobaoshe.

Teiwes, Frederick C., and Warren Sun. 2007. The End of the Maoist Era: Chinese Politics during the Twilight of the Cultural Revolution, 1972-1976. Armonk, NY: M.E. Sharpe.

Vogel, Ezra F. 2011. Deng Xiaoping and the Transformation of China. Cambridge, MA: Harvard University Press.

Walder, Andrew G. 1994. "The decline of communist power: elements of a theory of institutional change." Theory and Society 23(April), 297-323.

Walder, Andrew G. 1995. "Local governments as industrial firms: an organizational analysis of China's transitional economy." American Journal of Sociology 101(2), 263-301.

Walder, Andrew G. (ed.). 1998. Zouping in Transition: The Process of Reform in Rural North China. Cambridge, MA: Harvard University Press.

Walder, Andrew G. 2014. "Rebellion and repression in China, 1966-1971." Social Science History 38 (3/4), 513-539.

Walder, Andrew G. 2015. China under Mao: A Revolution Derailed. Cambridge, MA: Harvard University Press.

Walder, Andrew G. 2016. "Rebellion of the cadres: the 1967 implosion of the Chinese party-state." The China Journal 75, 102-120.

Walder, Andrew G., Andrew Isaacson and Qinglian Lu. 2015. "After state socialism: the political origins of transitional recessions." American Sociological Review 80(2), 444-468.

Westad, Odd Arne. 2010. "The great transformation: China in the long 1970s." In Niall Ferguson, Charles S. Maier, Erez Manela and Daniel J. Sargent (eds.), The Shock of the Global: The 1970s in Perspective. Cambridge, MA: Harvard University Press, 65-79.

White, Lynn T. III. 1998. Unstately Power: Local Causes of China's Economic Reforms. Armonk, NY: M.E. Sharpe.

Yang, Dali. 1996. Calamity and Reform in China: State, Rural Society, and Institutional Change since the Great Leap Famine. Stanford, CA: Stanford University Press.

Yang, Jisheng. 2012. Tombstone: The Great Chinese Famine, 1958-1962 (Stacy Mosher and Guo Jian (trans.)). New York: Farrar, Straus and Giroux. 